\title{
フェライト系PMステンレス鋼の磁気特性に及ぼす $\mathrm{N}$ 吸収の影響
}

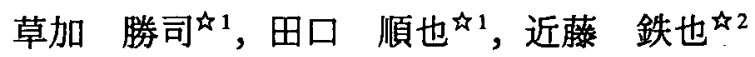 \\ 1 大同工業大学, ₹ 457-8530 名古屋市南区潼春町 10-3. \\ 4 2 大同特殊鋼(橵)，广 457-0811 名古屋市南区大同町 2-30.
}

\section{Effect of N Absorption on Magnetic Properties of Ferrite-type PM Stainless Steels}

\author{
Katsushi Kusaka ${ }^{\star 1}$, Jyunya Taguchi ${ }^{\star 1}$ and Tetsuya Kondo ${ }^{\not 2}$ \\ 4 1 Daido Institute of Technology, 10-3 Takiharu-cho Minami-ku, Nagoya 457-8530. \\ ${ }^{\star 2}$ Daido Steel Co., Ltd., 2-30 Daido-cho Minami-ku, Nagoya 457-0811.
}

Received March 2, 2001

\section{SYNOPSIS}

The objective of this study is mainly to elucidate the effect of $\mathrm{N}$ addition on $\mathrm{DC}$ magnetic properties of $\mathrm{Fe}-\mathrm{Cr}$ type PM stainless steels bearing $\mathrm{Cr}$ of 9-24 wt\%. The magnetic measurement was practically carried out about specimens before and after the heat-treatment upto $1173 \mathrm{~K}$ in a $\mathrm{N}$ atmosphere. Finally, these data were evaluated in the terms of degradation of magnetic properties by $\mathrm{N}$ absorption, together with residual pores.

The results obtained were summarized as follows:

(1) Fe-Cr alloys, heated at $673 \mathrm{~K}$ in a $\mathrm{N}$ gas show higher magnetic induction (B)/maximum permeability $\left(\mu_{\mathrm{m}}\right)$ and also, lower coercive force $(\mathrm{Hc})$ in the vicinity of $\mathrm{Cr}: 12 \mathrm{wt} \%$, as well as as-sintered ones.

(2) When $\mathrm{Fe}-\mathrm{Cr}$ alloys are heated upto $1173 \mathrm{~K}$ in a $\mathrm{N}$ gas, the magnetic properties, especially $\mu_{\mathrm{m}}$, are wholly degraded, and the peak values mentioned-above are shifted to $\mathrm{Cr}$ rich region.

(3) For the degradation ratio, $\Delta \mathrm{B} / \mathrm{B}$ increases abruptly at $1073 \mathrm{~K}$ corresponding to $\mathrm{N}$ absorption, while $\Delta \mu_{\mathrm{m}} / \mu_{\mathrm{m}}$ linearly increases with the rise of heat-temperature though fairly scattered due to being structure-sensitive.

(4) Roughly evaluated including HIPed materials, magnetic properties are degraded with the rise of amount of N, austenite-former, in relation to ferrite-former and also, non-magnetic $\mathrm{Cr}$ constituent.

(5) Specimens sintered at higher temperature tend to absorb small amount of $\mathrm{N}$ and hence, show better magnetic properties, although the correlation of $\mathrm{N}$ content to sintered density $(\rho)$ is not apparently larger.

\section{KEY WORDS}

magnetic properties, $\mathrm{N}$-absorption, magnetic induction, maximum permeability, austenite/ferrite formers

\section{1 緒言}

ソフト磁性材料の一種である Fe-Cr 系ステンレス鋼は高強 度・耐食性磁性部品として使用”され，最近ではEFIや車載セ ンサの構成部品などの形でも組込まれている，その内，セン サ類や一部のアクチュエータでは，複雑形状なため粉末治金

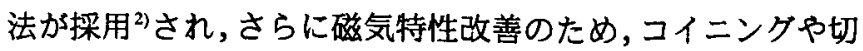
削加工後の歪み取り/磁気焼鈍年吕) などの加熱処理が廉価な $\mathrm{N}$ 含有䨌囲気中で実施される場合がある。しかし，Fe-Cr系PM ステンレス鋼の場合，基地中の $\mathrm{C}$ と $\mathrm{N}$ の親和力が強く ${ }^{6)}$, 窒 化しやすい上，さらに〜 10\% の残留気孔》が比表面積を增大 し， N 吸収を助長 ${ }^{8,9}$ することが容易に想定される。

そこで著者らは, Fe-(9 24)Cr焼結体のN吸収に伴う磁気特 性の変化を $\alpha / \gamma$ 相変態 ${ }^{3}$ や残留気孔との関係で検討し, N許容
限を明確化することとした。

\section{2 試料およひ実験方法}

高周波誘導炉により溶解し，水噴蓩することにより 5 種類 の低炭素の Fe-Cr 系合金粉末を製造し， -100 メッシュに分級 した.

Table1 に粉末の化学成分を示す.

これら粉末をプレス成形し，環状試験片 $(45 \phi \times 33 \phi \times 6 \mathrm{~mm})$ の形の圧粉体を作製した.この際，成形圧力は $490 \mathrm{MPa}$ 一定 とし, $1 \%$ ステアリン酸要鉛による混合润滑法を採用した.こ れら圧粉体は脱ろう後, 1373〜1573 Kで $1 \mathrm{hr}$ 真空焼結を施し， 焼結密度を測定した。

別途, $\mathrm{Fe}-16 \mathrm{Cr}(\mathrm{C})$ 合金粉末をステンレス鋼製のカプセル 
$(115 \phi \times 140 \mathrm{~mm})$ に加圧充填・密封後, $1473 \mathrm{~K} / 100 \mathrm{MPa}$ で HIP 処理を施し，100\%密度の比較材とした。これより前記環状試 験片を削り出し，1173Kで歪み取り焼鈍して供試材とした。

直流磁気湘定は B-Hカーブトレーサ (理研電子製) を使用 し,最大印加磁界は磁化曲線がほぼ飽和する $800 \mathrm{~A} / \mathrm{m}^{109}(10 \mathrm{Oe})$ に設定した，磁気測定後の環状試験片は巻き民し，真空・ガ ス雾囲気炉を使用し，N雾囲気中で 673〜1173Kで $1 \mathrm{hr}$ 加熱処 理を施した．ただし，加熱温度は主に $\alpha$ 相中での窒化現象を 取り扱うため, $\mathrm{Fe}-\mathrm{Cr}(\mathrm{C}, \mathrm{N})$ 平衡状態図 (後出) ${ }^{11)}$ 上 $\gamma$ ループの

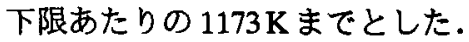

窒化処理後の環状試験片は再度巻線し，同条件で磁気測定 を行い, 窒素吸収による磁気特性の変化 ${ }^{12}$ (劣化率 $\left.=\Delta \mathrm{X} / \mathrm{X}\right)$ を

Table 1 Chemical compositions of powders.

wt.\%

\begin{tabular}{|c|c|c|c|c|c|c|c|c|}
\hline Type & $\mathrm{C}$ & $\mathrm{Si}$ & $\mathrm{Mn}$ & $\mathrm{P}$ & $\mathrm{S}$ & $\mathrm{Ni}$ & $\mathrm{Cr}$ & $\mathrm{N}$ \\
\hline $\mathrm{A}$ & 0.017 & 0.82 & 0.15 & 0.007 & 0.005 & 0.04 & 8.98 & 0.009 \\
\hline $\mathrm{B}$ & 0.013 & 0.80 & 0.18 & 0.021 & 0.005 & 0.09 & 12.35 & 0.014 \\
\hline $\mathrm{C}$ & 0.014 & 0.86 & 0.16 & 0.025 & 0.005 & 0.14 & 16.23 & 0.025 \\
\hline $\mathrm{D}$ & 0.003 & 0.76 & 0.06 & 0.001 & 0.002 & 0.02 & 20.06 & 0.020 \\
\hline $\mathrm{E}$ & 0.003 & 0.94 & 0.07 & 0.003 & 0.003 & 0.03 & 23.66 & 0.019 \\
\hline
\end{tabular}
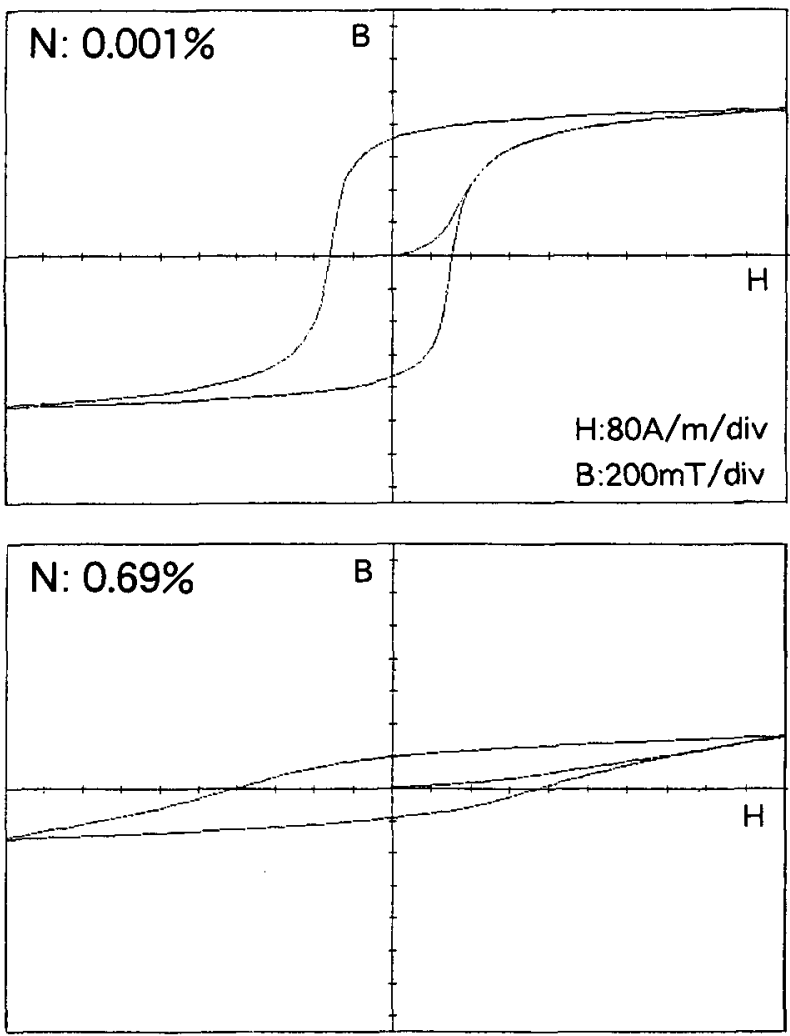

Fig.1 Example of DC B-H curves for specimens before and after nitriding (at $1173 \mathrm{~K}$ ).
算出した。これら粉末焼結体から切り出した試料を不活性ガ 又融解一熱伝導度法 (JIS G 1228) による N-定量分析を行い， 磁気特性と対比し，特性評価の判断資料とした。

\section{3 実験結果および考察}

Fig.1に(予備実験として) Fe-16Cr(C) 圧粉体を $1473 \mathrm{~K} て ゙$ 真 空焼結後, $1173 \mathrm{~K}$ で窒化処理した試料の直流磁界中での B-H 曲線の測定結果を例示する．もとの試料の B-H曲線に比へ， 窒化処理すると，初磁化曲線の立上がりが遅く，つまり最大 透磁率 $\mu_{\mathrm{m}}$ が減少し，同時に磁束密度(B)レベルも低下して，飽 和しにくくなる傾向が見られる。

Fig.2〜4にA〜E圧粉体を $1473 \mathrm{~K}$ で真空焼結した試料の直 流磁気特性のCr量および窒化温度による変化を例示する。こ

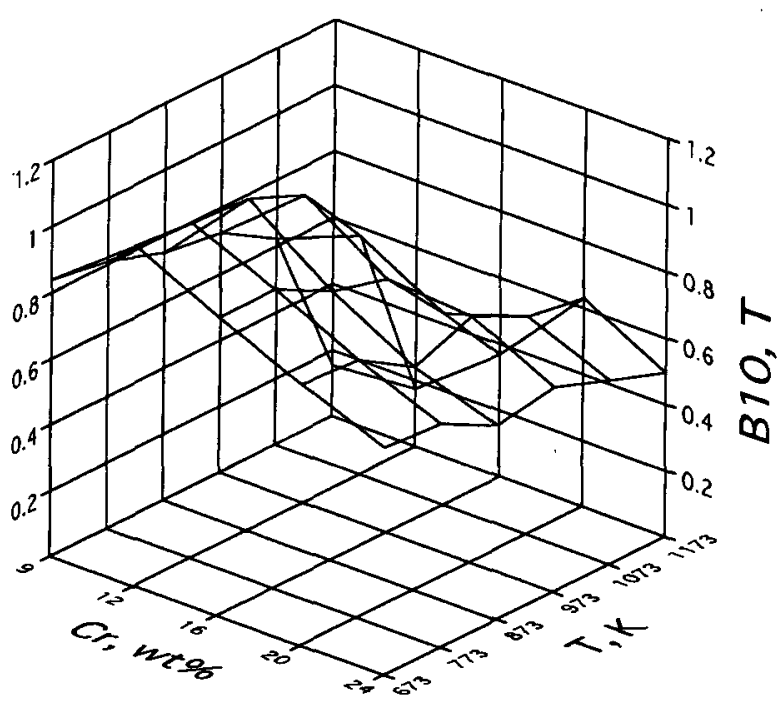

Fig.2 Change of magnetic induction (B) with $\mathrm{Cr}$ content and nitriding temperature (sintered at $1473 \mathrm{~K}$ ).

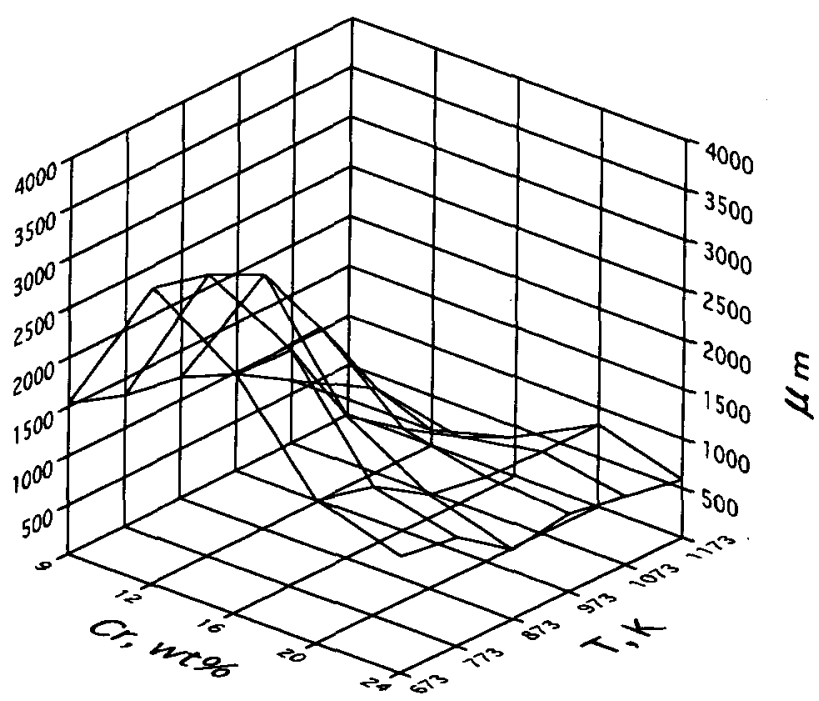

Fig.3 Change of maximum permeability $\left(\mu_{\mathrm{m}}\right)$ with $\mathrm{Cr}$ content and nitriding temperature. 
れら磁気特性を $\mathrm{Cr}$ 量側から見ると，Fig.2,3 の磁束密度 B，最大 透磁率 $\mu_{\mathrm{m}}$ とも公化温度が $673 \mathrm{~K}$ では $\mathrm{Cr} 12 \mathrm{wt} \%$ で最大值をと り，既報》と同様の傾向を示している.ただし，本報より高密 度化し，高特性化しやすい条件下にある.この内, Cr 9 $\mathrm{w}$ t\%で $\mathrm{B}, \mu_{\mathrm{m}}$ 両特性が低下するのは, $\mathrm{Fe}-\mathrm{Cr}$ 平衡状態図 ${ }^{11)}$ から $1473 \mathrm{~K}$ 焼結が $\gamma$ ループ内で行われ ${ }^{13)}$ ，冷却後も $\alpha$ 基地中に非磁性の $\gamma$ 相を残留 ${ }^{14}$ するためと考えられる.実際，X線回折 ${ }^{14)}$ では，焼 結試料に〜14 Vol\%の $\gamma$ 相が検出された. また，高 $\mathrm{Cr}$ 量側で 磁束密度 B が渐減するのは， $\mathrm{Fe}$ に対し非磁性のCr元素が増加

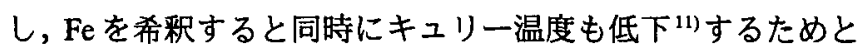
解される.しかし，窒化温度が高い領域ほど $\mathrm{B}, \mu_{\mathrm{m}}$ 両特性値と も減少し, $1173 \mathrm{~K}$ になると最大値はむしろ高 $\mathrm{Cr}$ 量側に移る傾 向が見られる.

一方, Fig.4の保磁力 Hc も $673 \mathrm{~K}$ では Cr 16wt\% で最小 (最 良)値をとるが, 窒化温度が高い領域ほど增加し，1173Kにな るとやはり最小值は高 $\mathrm{Cr}$ 量側に移る傾向が見られる.

本来, 最大透磁率 $\mu_{\mathrm{m}}$ と保磁力 $\mathrm{Hc}$ は構造敏感な特性值 ${ }^{(4)}$ で, 両者は密接な関係 ${ }^{15}$ にあり，本実験のC $\mathrm{r}$ 量に対しても排反的 に変化 ${ }^{16)}$ するとみなされるため, 以後磁気特性として磁束密 度 $\mathrm{B}$ ，最大透磁率 $\mu_{\mathrm{m}}$ により代表させることとした。

Fig.5 は Fig.2,3における磁気特性の (窒化) 温度依存性を調 べるため，Cr量をパラメータとして磁束密度 $\mathrm{B}$, 最大透磁率 $\mu_{\mathrm{m}}$ の窒化温度による劣化率 $(=\Delta \mathrm{X} / \mathrm{X})$ の変化を表したものであ る. 磁束密度 $B$ の劣化率 $\Delta B / B$ は左端 $(T=0$ 無処理) から始ま り，加熱温度とともに徐々に減少し，1073Kあたりから急滅 する. また最大透磁率 $\mu_{\mathrm{m}}$ の劣化率 $\Delta \mu_{\mathrm{m}} / \mu_{\mathrm{m}}$ は構造敏感なため か測定值がばらつくが，窒化温度に対しほぼ直線的に減少す る傾向が見られる．総じて，焼結試料は $1073 \mathrm{~K}$ 以上で窒化反 忍が進み (Fig.6)，特性劣化するが， B, $\mu_{\mathrm{m}}$ 両特性とも低 $\mathrm{Cr}$ 量 側，つまり Cr16wt\%以下での劣化が目立つ.しかし，Fig.5で， 同じ Cr $16 \mathrm{wt} \%$ でも HIP 材 (口, 気孔率ゼロ) は全く特性劣化

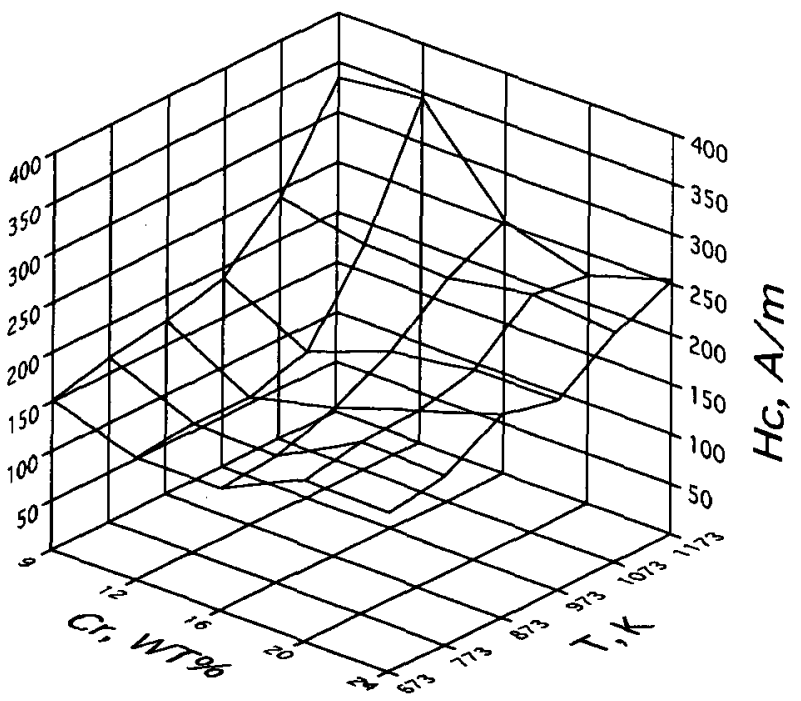

Fig.4 Change of coercive force (Hc) with $\mathrm{Cr}$ content and nitriding temperature.
を起こさず，対応する $\mathrm{N}$ 量もほぼ $0.01 \mathrm{wt} \%$ 一定であることよ り，焼結試料のN吸収による特性少化は焼結温度，つまり気 孔形態の影響を受ける8) と想定される.

そこで, Fig.7,8に1373〜1573K K焼結試料の窒化処理 ( $\geqq 673 \mathrm{~K}$ ) 後の磁気特性と $\mathrm{N}$ 吸収量との関係を $\mathrm{Cr}$ 量をパラメータとして 示した. Fig.6と同様，いずれのCr量，焼結温度ともN量は一 義的な(窒化)温度依存性をもつため, 磁気特性は高 $\mathrm{N}$ 量領域 で比較すればよいことになる。

まずFig.7の磁束密度Bと N量との関係は右下がりの曲線群 となり，Nを吸収するほど特性劣化 ${ }^{17}$ するほか，これら曲線
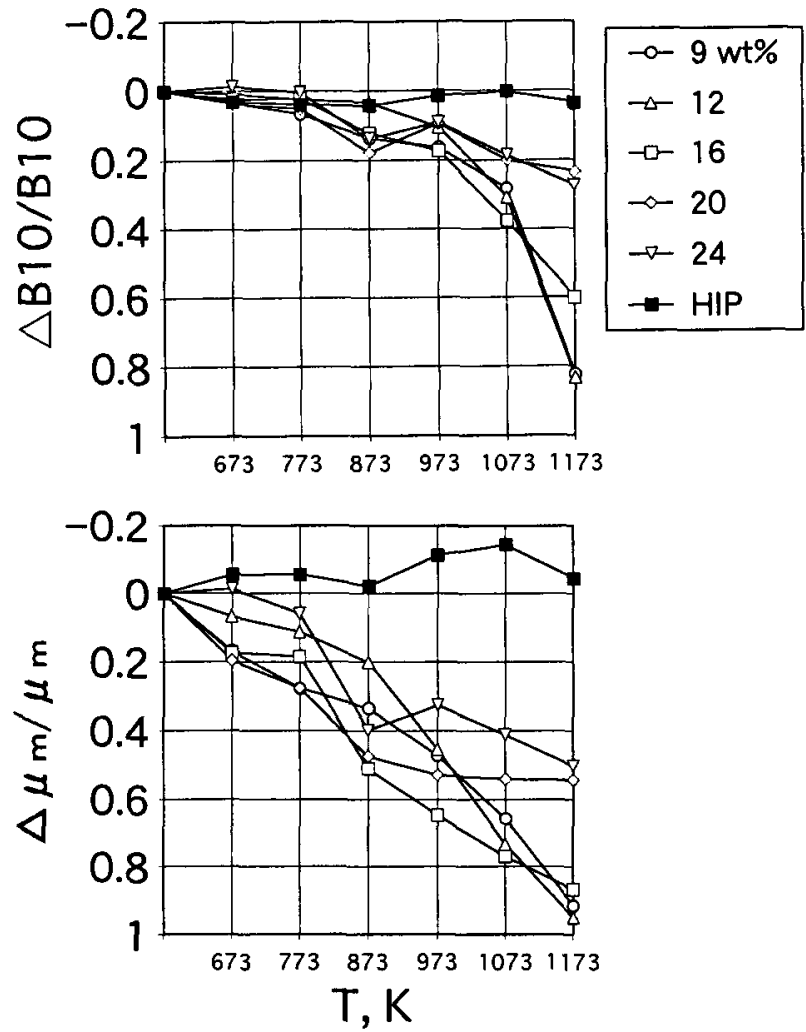

Fig.5 Effect of heat-temperature on magnetic properties (sintered at $1473 \mathrm{~K}$ ).

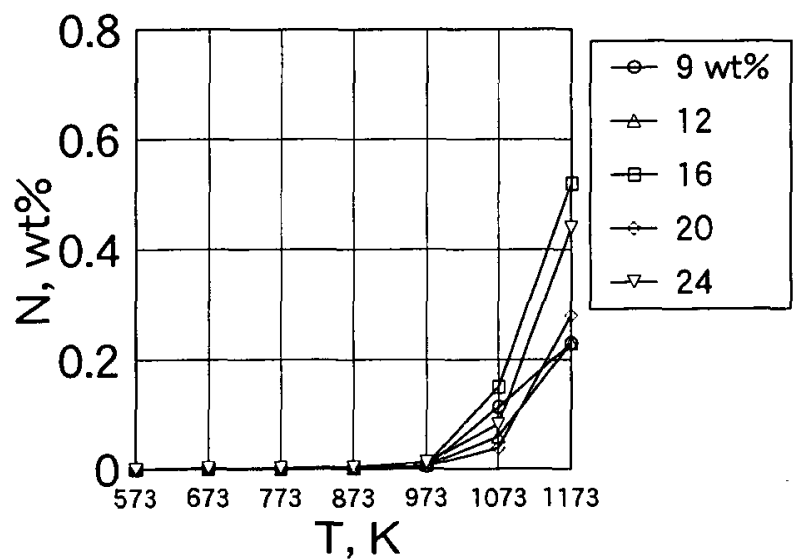

Fig.6 Change of N-content with heat-temperature (sintered at $1473 \mathrm{~K})$. 

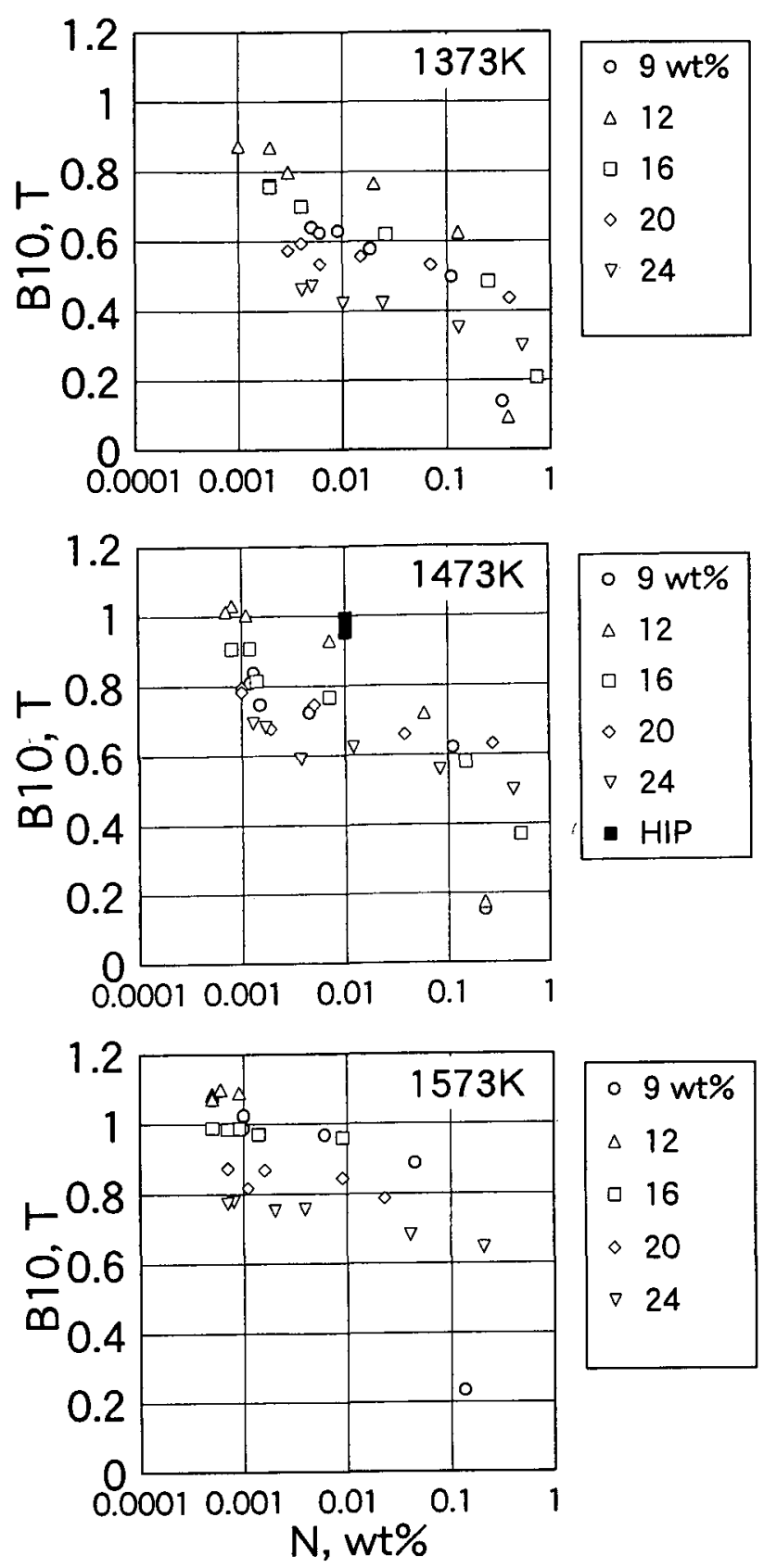

Fig.7 Relationship between magnetic induction (B) and N-content (sintered at $1373-1573 \mathrm{~K}$ ).

群は焼結温度が高いほど左上方に移動し，低Nかつ高特性化 する傾向にある。

一方, Fig.8の最大透磁率 $\mu_{\mathrm{m}}$ と $\mathrm{N}$ 量の関係も前記 $\mathrm{B}$ と同様で, $\mathrm{N}$ を吸収するほど特性劣化するが，低 $\mathrm{N}$ 量領域 $(\mathrm{N} \leqq 0.01 \mathrm{wt} \%)$ での N-依存性が大きく，構造敏感な特性値 ${ }^{14)}$ を反映してい る. 因に， B, $\mu_{\mathrm{m}}$ 両特性と $\mathrm{N}$ 量の関係を $\mathrm{Cr}$ 量ことに相関係数 をとると, 前者で〜0.92, 後者で〜0.69 となり, 前者の方が収 束性がよいことが数值的にも確認される．ただし，1473K焼 結試料は B, $\mu_{\mathrm{m}}$ 両特性とも HIP材 $(1473 \mathrm{~K} / 100 \mathrm{MPa})$ より低 $\mathrm{N}$ か つ高特性化 (左上方)しているが, これは真空焼結時の脱窒反
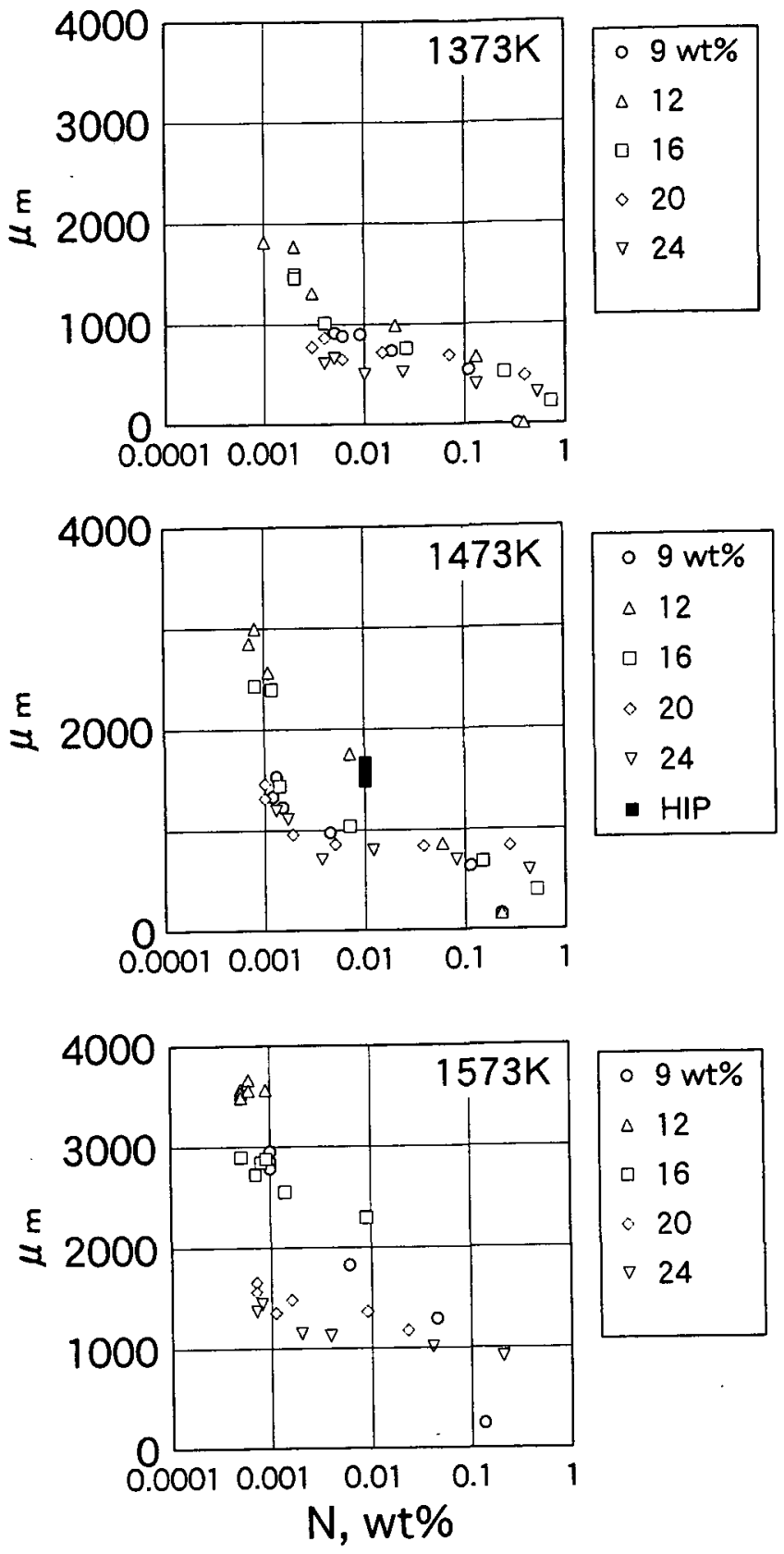

Fig.8 Relationship between maximum permeability $\left(\mu_{\mathrm{m}}\right)$ and Ncontent.

応 ${ }^{18)}$ に起因すると判断される.

Fig.7,8で焼結体の磁気特性は焼結温度が高いほど改善され る原因は，緻密化による残留気孔の減少効果 $\left.{ }^{10}\right)$ のほか，それ に伴う比表面積の減少が $\mathrm{N}$ 吸収速度を遅らせる ${ }^{8,9}$ 相乗効果に よると判断される. しかし，Fig.9に対応する焼結試料の窒化 処理 $(\geqq 673 \mathrm{~K})$ 後の $\mathrm{N}$ 量と焼結密度 $\rho$ との関係を見ると, HIP 材 $(\boldsymbol{\square})$ を除外しても，N吸収速度の密度依存性は比較的小さ い.この際，高温焼結による粒成長，つまり粒界密度の減少 という面”からも $\mathrm{N}$ 吸収速度を漣らせている可能性がある.

ところで, Fig.7,8の焼結体の磁気特性が, 窒化処理により 


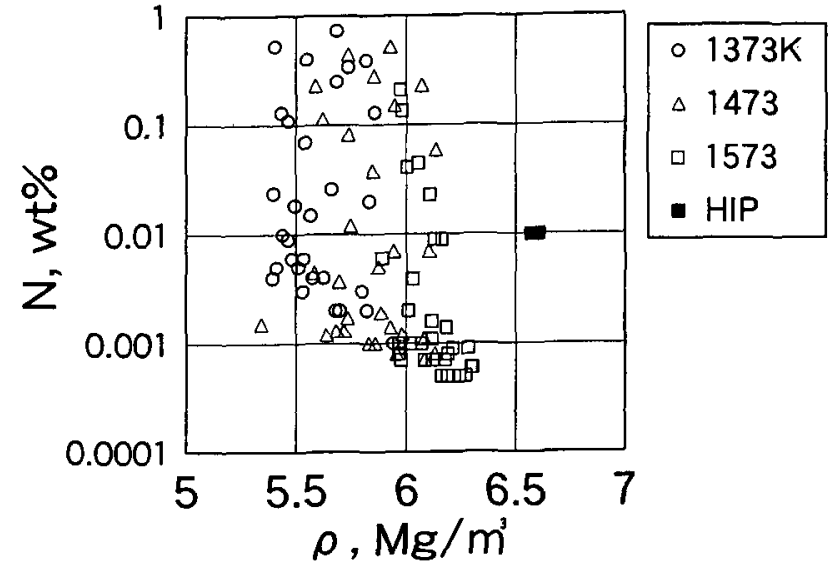

Fig.9 Relationship between N-content and sintered density $(\rho)$.

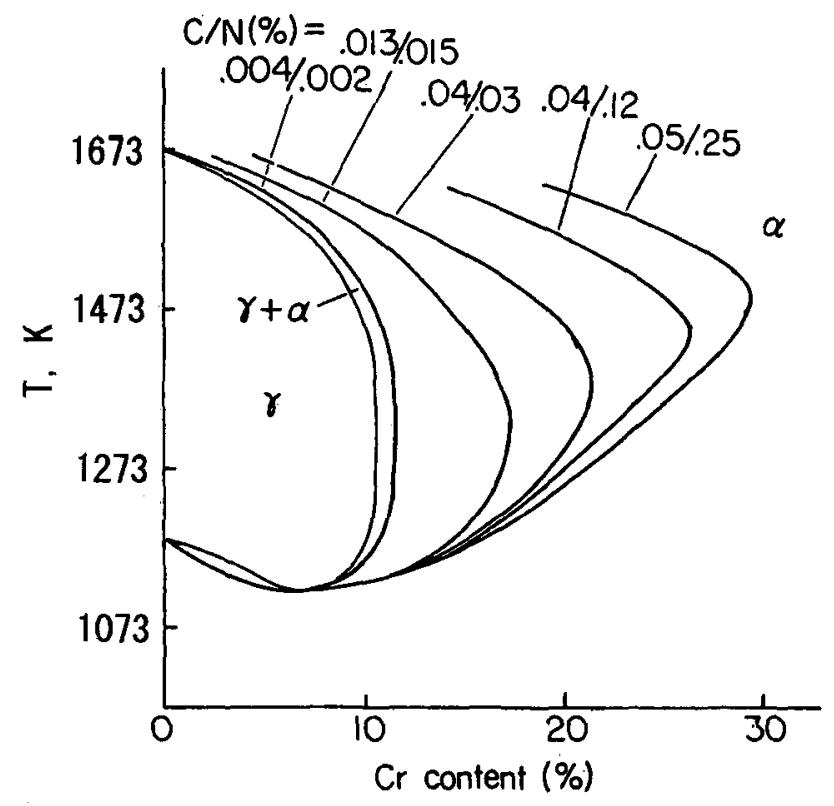

Fig.10 Change of $\gamma / \alpha$ phase boundary in Fe-Cr alloy with $\mathrm{N}$-content.

$\mathrm{N}$ 吸収するほど特性劣化する原因として, $\mathrm{N}$ 固溶域での $\alpha \rightarrow$ $\gamma$ 相変態による非磁性化のほか， $\alpha$ 基地中の侵入型元素の $N や$ $\mathrm{Cr}-\mathrm{N}$ 系析出物による磁壁移動の阻害現象 ${ }^{16)}$ などが挙げられ る. 前者は N がオーステナイト生成元素のため, Fig.10の Fe$\mathrm{Cr}$ 系平衡状態図 ${ }^{11)}$ 上， $\mathrm{N}$ を吸収するほど $\gamma$ ループは右方に広 がるが，空化処理は $1173 \mathrm{~K}$ 以下に限定したため $\gamma$ 相の生成は 比較的小さい。むしろ，1373 1573 K 焼結が低 $\mathrm{C}$ 量側では $\gamma$

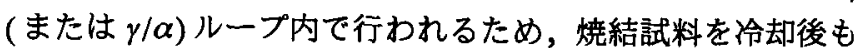
$\alpha$ 基地中に非磁性の $\gamma$ 相を残留 ${ }^{14)} し ， N$ の固溶度を増加させ る. 実際, 溶製材でも低 $\mathrm{Cr}$ 量側では $1200 \mathrm{~K}$ 付近から N吸収が始

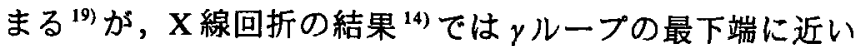
$\mathrm{Cr} \sim 9 \mathrm{w} t \%$ では, $1173 \mathrm{~K}$ の窒化処理により $\gamma / \alpha$ 相比率は $14 \rightarrow 31$ Vol\% (N: 0.34 wt\%) と增加し， $\gamma$ 相中にも $\mathrm{Cr}_{2} \mathrm{~N} や \mathrm{CrN}$ などの窒 化物が析出〉しやすくなるのを示唆する.いずれにしても, N
吸収により非磁性 $\gamma$ 相の占有率が增加し，さらに $\alpha$ 基地中の 侵入元素としてのNによる(結晶)格子歪や Cr-N 系析出物に よるピニング効果 ${ }^{16)}$ か磁壁移動を阻害し，ソフト磁性材料と しての特性劣化を招いたものと推定される。

\section{4 結袞}

$\mathrm{Fe}-\mathrm{Cr}$ 系PMステンレス鋼の磁気特性はプレス焼結しやすい $\mathrm{Cr} 12 \mathrm{wt} \%$ 付近で良好となり，それより低Cr量側では焼結時の $\gamma$ 相が残存し，また高 $\mathrm{Cr}$ 量側では非磁性元素のCr濃化のため 磁気的には不利となる。これに窒化処理を施すと，1073K以 上で基質中の $\mathrm{N}$ 濃化 $(\mathrm{N} \geqq 0.01 \mathrm{wt} \%)$ が目立ち，磁束密度 B 劣化が起こる. しかし，構造敏感な最大透磁率 $\mu_{\mathrm{m}}$ は $\mathrm{N}$-感受 性が強く，さらに低 $\mathrm{N}$ 量領域から特性劣化が始まる．このN 吸収による特性劣化の度合いは $\mathrm{Cr}$ 量や焼結温度にも依存し， 特に焼結温度が高く，残留気孔が少ないほど紸和され，100\% 密度の HIP 材では〜1173K まではN吸収は起こらず，特性劣 化もない。

概して, 本実験条件下では $\mathrm{N}$-雾团気中, 〜 $1000 \mathrm{~K}$ 以下の加 熱処理なら磁気特性の劣化は比較的小さく，実害はないとい える.なお，本研究では磁気特性の劣化原因，つまり $\mathrm{N} の$ 挙 動や存在形態については溶製材の知見を援用し，詳細な追究 は行わなかったが, 焼結材特有のN吸収による磁気特性の劣 化現象について明らかとなった。

最後に本研究を進めるにあたり，こ協力頂いた大同工業大 学橋立光男氏，大同特殊鋼㑣技術開発研究所および粉末事業 部の方々に深く謝意を表する.

\section{文献}

1）長谷川正義ほか : ステンレス鋼便臨，第 3 版，日刊工業新 聞社, (1994)150, 1167 .

2) J.A.Bas and J.Pulg: "High Density Sintered Magnetic Materials in Automotive Application", MPR., 39(1988)732-738.

3) J.H.Reinshagen and J.C.Witsberger: "Processing and Properties of 400 Series PM Stainless Steels", 42(1991)38-44.

4) S.Shah: "Properties of 410L P/M Stainless Steel Antilock Brake Sensor Ring", SAE Tech. Paper Ser. No.930449, (1993)1-11.

5）草加勝司，竹下達，近藤鉄也: "ソフト磁性材料の磁気特 性に及ぼす応力/歪の影響 ", 粉体および粉末治金, 46 (1999)666-672.

6) H.K.Feichtinger and X.Zhong: "Powder Metallurgy of High Nitrogen Steels", Powder Met. Internal, 22(1990)7-10, 12-13.

7) 加藤哲男, 草加勝司, 加藤俊宏 : " $\mathrm{Fe}-\mathrm{Cr}_{\mathrm{r}}$ 烧結合金の磁気特 性について ", 電気製鋼 , 48(1977)144-150.

8）秋田利彦, 湯浅秀典, 山田弘光, 庄司啓一郎 : " 焼結 $\mathrm{Cr}$ 合 金の窒化層 ", 粉体および粉末治金, 26(1979)100-104.

9）中村展弘，高木節雄，徳永洋一: "12mass\%Cr フエライト鋼 焼結体の窒化挙動に及ほす気孔の影響",粉体および粉末 冶金, 41(1994)468-473.

10) 草加勝司, 鈴木智也, 近藤鉄也 : "フエライト系 $\mathrm{PM}$ ステン 
レス鋼の磁気特性に及ぼす残留気孔の影響",粉体および 粉末治金, 45(1998)685-691.

11) E.Baerlecken, W.A.Fischer and K.Lorenz: "Untersuchungen uber das umwandlungsverhalten, die Kerbschlagzahigkeit und die Neigung zur Interkristallinen Korrosion von Eisen-ChromLegierungen mit Chromgehalten bis 30\%", Stahl u Eisen, 81 (1961)768-778.

12) J.M.Capus and K.Hajmrle: "The Effect of Sintering Atmospheres on Magnetic Properties", Powder Met. Internal, 15(1983)193196.

13）鎌田政智, 中村展之, 後藤秀人, 徳永洋一："Fe-8mass\% Cr 合金の高温相組織と焼結機構 ", 粉体および粉末治金, 40 (1993)914-918.

14) K.H.Moyer and D.S.Madan: "The Influence of Chromium Content on the Magnetic Properties and Corrosion Resistance of Admixed Stainless Steels", Adv. Powder Met. Parti. Mater., 17(1996)17, 13-22.

15) F.J.G.Landgraf et al.: "Effect of Annealing on Magnetic Properties of Fe-47.5\%Ni Alloy", J. Mater. Eng., 11(1989)4549.

16) 近角総信ほか: 磁性体ハンドブック, 朝倉書店,(1975)909.

17) F.G.Hanejko, H.G.Rutz and C.G.Oliver: "Effect of Processing and Materials on Soft Magnetic Performance of Powder Metallurgy Parts", Adv. Powder Met. Parti. Mater., 6(1992)375403.

18）草加勝司: "水噴霧ステンレス鋼粉の焼結挙動に及ぼす脱 窒の影響について", 粉体および粉末冶金, 28(1981)8-14.

19）中村展之, 高木節雄, 鐮田政智, 徳永洋一: "12\%Cr フエラ イト系ステンレス鋼粉圧粉体の窒素雲囲気における窒化 および焼結機構 ", 鉄と鋼 , 79(1993)1204-1209. 